\title{
DIVERSITY OF INSECT, MITE AND NEMATODE SPECIES IN TEA ECOSYSTEM OF BANGLADESH
}

\author{
Paul, S. K., M. Ahmed, M. S. A. Mamun and M. J. Alam \\ Bangladesh Tea Research Institute, Sreemangal, Moulvibazar, Bangladesh
}

\begin{abstract}
The study was undertaken on insect, mite and nematode species diversity in Bangladesh Tea Research Institute (BTRI) main farm, Baraoora and Phulcherra tea estates in Sreemangal, Bangladesh from the period of 2014 to 2015. The study was done through direct field observations, sweeping net, food trap, sticky trap, light trap and Baermann Funnel method. A total of 71 insect, mite and nematode species was recorded belonging to 45 families under 14 orders. Among these, $25.35 \%$ species were foliar insects and mites, $26.76 \%$ soil insects and nematodes, $21.13 \%$ beneficial insects and $26.76 \%$ butterflies. All the foliar and soil insects, mites and nematodes were found as recognized pests of tea. The highest number of individuals among foliar pest was the red spider mite (Oligonychus coffeae) and the lowest number was the coffee red borer (Zeuzera coffeae). Of the soil pests, $77.47 \%$ species were termites, $14.33 \%$ nematodes, $4.86 \%$ field cricket, $2.63 \%$ mole cricket and $0.72 \%$ cockchafer grub. Regarding the soil pests, live wood termite (Microtermes obesi) was the highest and dagger nematode (Xiphinema sp.) was the lowest in number. One species of foliar insect, looper caterpillar (Hyposidra infixaria) and three species of nematodes, viz. reniform nematode (Rotylenchulus sp.), ring nematode (Criconemoides sp.) and dagger nematode (Xiphinema sp.) were recorded for the first time as tea pest in Bangladesh. In case of beneficial insects, $81.49 \%$ species were predators, $16.73 \%$ parasitoids and $1.78 \%$ parasites. Lady bird beetle (Micraspis discolor) was the highest in number and anthocorids (Anthocoris sp.) were the lowest. Nineteen species of butterflies were found. Of the observed butterflies, lemon emigrant (Catopsilia pomona) was the highest and large oakblue (Arhopala amantes) was the lowest in number. According to pest status, tea mosquito bug, red spider mite, thrips, looper caterpillar, live wood termites, root knot nematode and root lesion nematode were major, and the rest of those were occasionally regarded as minor pest. The population of most of the pest species was higher in peak cropping season (April-November), whereas the lowest population was recorded in off season (December-February). According to diversity indices, the diversity of foliar pest was higher than the other groups and the foliar pest was more evenly distributed in comparison to soil, beneficial insects and butterflies.
\end{abstract}

Key words: Biodiversity, insects, mites, nematodes, tea ecosystem.

\section{INTRODUCTION}

Tea is an important non-alcoholic health beverage and cash crop of Bangladesh. It is a long established plantation crop of enormous economic importance to Bangladesh meeting the entire domestic demand as well as export. Now it is one of the largest agro-based industries in the country. There are 162 tea estates producing 66.35 million $\mathrm{kg}$ of made tea (Anonymous 2016). There are 15 small holders and 498 small growers in Panchagarh district. Tea is also grown at Bandarban, Khagrachari and Rangamati in Chittagong Hill Tracts as small holders (34) producing $6592 \mathrm{~kg}$ of made tea (Anonymous 2015).

Bangladesh tea is grown in the three fairly divergent ecological zones of category, namely (i) Surma valley in greater Sylhet, (ii) Halda valley in Chittagong and (iii) Korotoa Valley in Panchagarh districts. The Surma valley is again subdivided into six valley circles, viz. North Sylhet, Juri, Lungla, Balisera, Monu-Doloi and Luskerpore (Sana 1989, Alam 1999, Ahmed 2005).

Tea ecosystem has a great influence on the biodiversity of various flora and fauna. This ecosystem is a complex agro-ecosystem comprising different types of biotic flora and fauna like tea plant, shade tree, other ancillary crops, insects, mites, diseases, soil microorganisms, birds, reptiles, amphibians etc. along with various abiotic elements including soil nutrients, sunshine, light, day length, rainfall pattern, 
cloudiness, wind velocity, temperature, relative humidity etc. (Sana 1989, Ahmed 2005). An extensive monoculture of a perennial crop like tea over an extensive and continuous area in an apparently isolated ecological zone in Bangladesh has virtually formed a stable ecosystem for widely divergent organisms. Besides the architecture of tea plantation, variability of plant types and the systematic interaction of various agro techniques like weekly tea plucking rounds, presence of shade and ancillary crops, intercultural operations etc. impose a significant impact on subsequent colonizing, stabilizing and distribution of different pests.

Tea plants are subjected to the attack of insects, mites and nematode pests. All parts of the plant, leaf, stem, root, flower and seed are fed upon by at least one pest species. Of the production, about $15 \%$ of its crop could be lost per year by various pests particularly insects, mites and nematodes if adequate control measures are not taken. Moreover crop losses to the extent of $50 \%$ or more may be inflicted by the advent of an epidemic or outbreak of specific pests in a particular season or tea estate. So far 25 insect, four mites and 10 nematode species have been recorded in Bangladesh tea (Sana 1989, Ahmed 2005). Due to climate change, pest infestation is increasing as well as pest status is changing. On the other hand, deforestation is resulting in the migration of forest pest to tea ecosystem (Antony et al. 2012). The indiscriminate use of synthetic pesticides has significant effect on the reduction of beneficial insect population resulting in pest resurgence and resurrection of minor pest to major one (Ahmed 2005). Natural biocontrol agents play an important role to regulate the pest population in tea ecosystem. Existence of more than one hundred species of indigenous natural biocontrol agents of tea pests including predators, parasites, parasitoids were recorded from the tea ecosystem (Borthakur et al. 2010).

The tea flowers are pollinated by insects. Tea is virtually self-sterile and almost entirely crosspollinated. Supplementary pollination produces more, larger, and heavier capsules, better viability, and higher grades of seeds. Butterflies are considered to be an important bio-resource and pollinating agent for the conservation of natural gene-flow in plant kingdom. A butterfly acts as a strong indicator of any pollution or of any change in an ecosystem.

Considering the above fact, the present study was undertaken to know the biodiversity of insect, mite and nematode species in the tea ecosystem of Bangladesh. This knowledge can help to provide information regarding their status, feeding habit, habitat, seasonal abundance and plant-insect interaction, and to predict where and when infestation will occur, what extend they will become, and how long they will last. Ultimately, this information tends to take decision making in an integrated pest management programme in tea.

\section{MATERIAL AND METHODS}

\section{Study area}

The study was conducted in the Bangladesh Tea Research Institute (BTRI) main farm, Baraoora and Phulcherra tea estates of Balisera valley circle at Sreemangal upazila of Moulvibazar district located in the North-East of Bangladesh (Fig. 1). Sreemangal is located in between $24^{\circ} 08^{\prime}$ and $24^{\circ} 28^{\prime}$ north latitudes and in between $91^{\circ} 36^{\prime}$ and $91^{\circ} 48^{\prime}$ east longitudes with an area of $450.74 \mathrm{sq} \mathrm{km}$. The climate of this area is considered to be sub-tropical monsoon with three distinct seasons: warm season (mid February to mid may), monsoon season (mid May to mid October) and cold season (mid October to mid February). The tea zones of Sreemangal experience dry season from November to April while the rainy season continues from May to October and above $80 \%$ of annual rainfall is obtained during JuneSeptember. Under Bangladesh condition it is observed that about $1400 \mathrm{~mm}$ of annual rainfall is a critical limit and the monthly mean temperature $<18.33^{\circ}$ and $>29.44^{\circ} \mathrm{C}$ seem unfavourable for tea (Ahmed 2005, Sana 1989). 


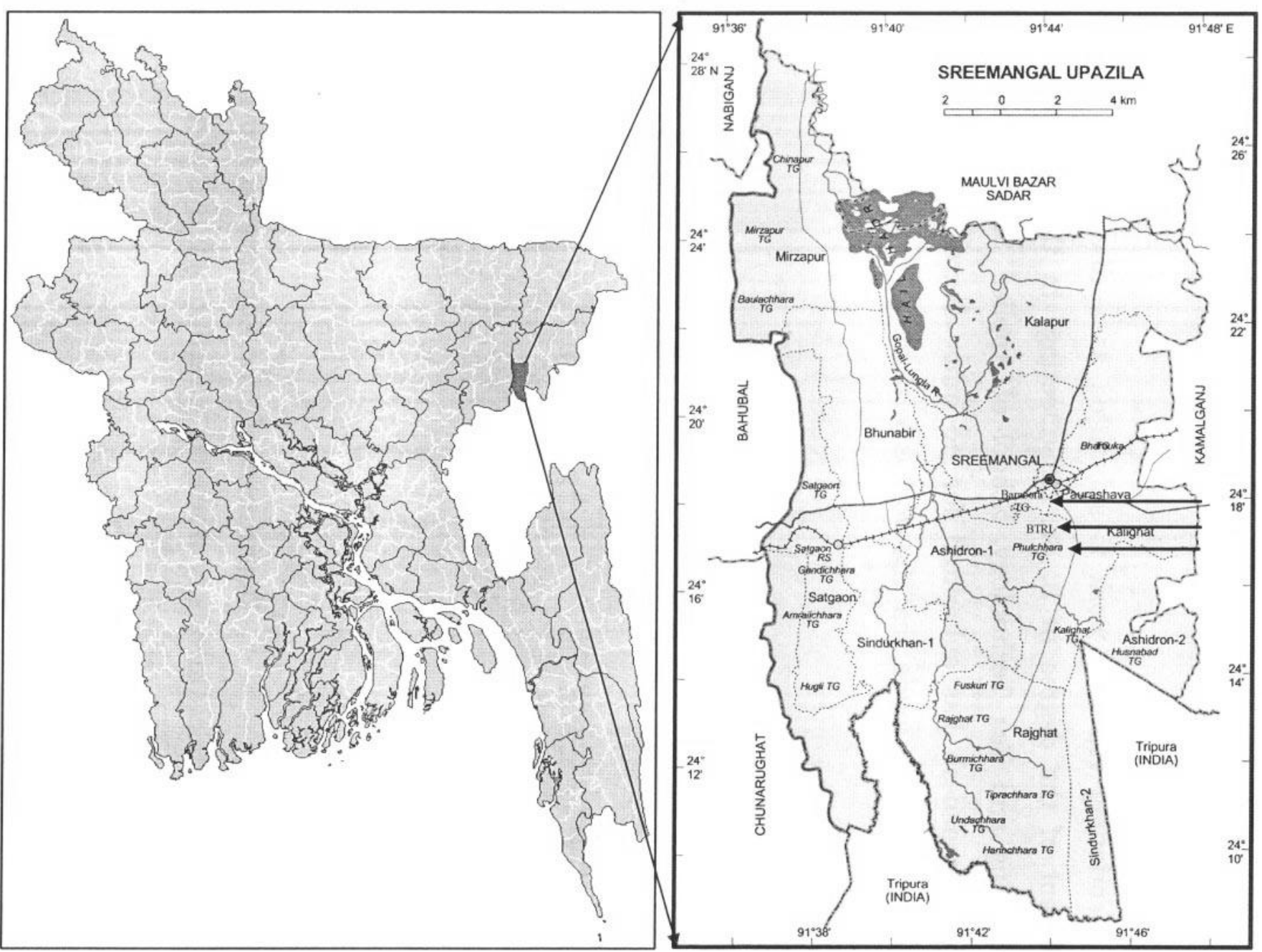

Fig. 1. The locations of the study area (source: Banglapedia 2003): *arrow marks indicating the three study locations at Sreemangal upazila.

Soil is highly weathered and extremely acidic with low fertility. Texturally the soil is predominantly loamy. Topography may be divided into three units, (i) Tillah or low hills-upto $90 \mathrm{~m}$ in height, about $32 \%$ of tea land is Tillah which is suitable for tea, but subjected to water stress and erosion; (ii) High flat- which are the higher valleys constitute about $45 \%$ of the land, 6-9 $\mathrm{m}$ above the plain and dissected by narrow valleys created by water erosion, soils are suitable for tea cultivation; and (iii) Low flatwhich are the valley floor and constitute about $23 \%$ of tea land, top soil may be relatively rich in organic matter but subjected to water logging (Alam 1999, Sana 1989).

\section{Observation technique}

Data were collected through direct field observations during the period between January 2014 and December 2015. Field observations were made at monthly intervals. Data were collected at early morning, mid-day, late afternoon and night in a day. Collected insect species were immediately kept in a jar with chloroform and carried to the Entomology laboratory of BTRI. Morphological characteristics of the collected insect species were studied under a stereomicroscope (40x) for taxonomic identification. For the identification of plant parasitic nematodes, their morphological characteristics were studied under a trinocular compound microscope (1000x) with camera facilities. Photographs were taken with a 
digital semi-SLR camera (canon SX 40HS) in order to confirm the identification. To identify insect, mite and nematode species, Ahmed (1997, 2005), Bashar (2013, 2014), Bingham (1907), Chen and Chen (1989), Evans (1992), Imms (1957), Mai and Lyon (1975), Mian (1998), Ross (1956) and Sana (1989) were followed. Already identified species placed in Entomology Laboratory, Bangladesh Tea Research Institute (BTRI) helped a lot in the process. The study period was divided into four seasons, viz. off season (December-February), early cropping season (March-May), peak cropping season (JuneSeptember) and late cropping season (October-November). Sampling was done in nursery, young tea ( $\leq 5$ years) and mature tea ( $>5$ years) areas. The relative abundance of some pest species was estimated on the basis of Economic Threshold Level (ETL) described by Mamun et al. (2014).

The Shannon-Wiener (1949) index and Simpson (1949) index of diversity and Evenness (quantifies how numerically equal the community is) of species in the study area were also calculated. The using formulas are:

$$
\begin{gathered}
\text { Simpson's Index of diversity, } \mathrm{D}=1-\operatorname{sum}\left(\mathrm{P}_{\mathrm{i}}^{2}\right) \\
\text { The Shannon-Wiener Index, } \mathrm{H}=-\operatorname{sum}\left(\mathrm{P}_{\mathrm{i}} \ln \left[\mathrm{P}_{\mathrm{i}}\right]\right)(\text { natural } \log ) \\
\text { Evenness, } \mathrm{E}=\frac{\mathrm{H}}{\ln (\mathrm{S})}(\text { natural } \log )
\end{gathered}
$$

Where,

$$
\begin{gathered}
\mathrm{P}_{\mathrm{i}}=\frac{\text { No. of individuals of a species }}{\text { Total no. of individuals of all species from the same group }} \\
\mathrm{S}=\text { No. of species from the same group observed }
\end{gathered}
$$

Systematic index with order, family, scientific name, common name, population status, feeding habit etc. were provided. Status of the pest was categorized as major and minor according to Ahmed (2005) and Sana (1989).

\section{Plot counting}

Plot counting method was followed for estimating sessile and non-sessile insects. A total of 15 plots was selected during the study period. Each plot size was $10 \times 10 \mathrm{~m}^{2}$. For non-sessile insect, direct observation was made for individual counting in each plot. In case of sessile insect, 100 mature leaves and 100 shoots (two leaves and one bud) were selected randomly. Both mature leaves and shoots were observed under a stereomicroscope (40x) in the Entomology Laboratory of BTRI.

\section{Sweeping net}

For capturing flying insect and butterflies, a sweeping net was used. The sweeping net was $0.30 \mathrm{~m}$ diameter fitted with a cone size bag of fine mesh nylon mosquito net and a wooden handle of $0.90 \mathrm{~m}$ long. Randomly sweeping was made in different locations of the study area.

\section{Food trap}

Food traps were used for determining termite population. Five types of food traps, such as saw dust, tissue paper, dried tender bamboo sleeves; jute sticks and susceptible soft timber were used as food traps (Ahmed, 2014). These food traps were scatteredly placed over the soil surface in the plot of $10 \times 10 \mathrm{~m}^{2}$.

\section{Sticky traps}

For non-sessile insects, sticky traps (adhesive traps) were also used. Commercially available two types of sticky traps, such as yellow and blue sticky card traps were placed in the tea field at $10 \mathrm{~m}$ distance from each other. The traps were hanged at the canopy level of the tea plants with a bamboo stick. The traps were checked once a week. 


\section{Light trap}

For collecting nocturnal insects, light trap was used. At night the collections were done by operating light trap (fluorescent tubes run from rechargeable 12V batteries) between 6.00 PM and 9.00 PM. The light was horizontally fixed on a bamboo pole and placed one $\mathrm{m}$ from ground. An engine oil coated polythene sheet was placed $15 \mathrm{~cm}$ below the light to stick insects. In order to prevent water entering in the traps, they were kept under permanent shade of a thatch.

\section{Baermann Funnel method}

For counting plant parasitic nematodes, soil samples were collected from rhizosphere of tea seedlings grown in poly tube from secondary nursery bed as well as young tea field using a soilsampling auger at a depth of $23 \mathrm{~cm}$ and about $5 \mathrm{~cm}$ from the base of the plants. Baermann funnel method with some modifications (Mian, 1998) was followed to extract nematodes from the soil samples.

\section{RESULTS AND DISCUSSION}

A total of 71 species of insects belonging to 45 families under 14 orders (viz. five foliar insects, five soil insects, seven beneficial insects and one butterfly order) was observed. Of them, 86.82\% species were foliar pests, $8.21 \%$ soil pests, $1.84 \%$ beneficial insects and $3.13 \%$ species butterflies (Tables $2-5$ ).

\section{Faunal composition}

The foliar pests were grouped into two types: insects and mites. Three species represented mites and the rest of them belonged to insects. Among the foliar insects, the frequently observed species $(\mathrm{n}=1541)$ was the thrips (Scirtothrips dorsalis) and the less frequent was the coffee red borer (Zeuzera coffeae). On the other hand, the frequently observed foliar mite species $(n=5312)$ was the red spider mite (Oligonychus coffeae) and the less frequent was the pink mite (Acaphylla theae) (Table 2). In case of soil pests species, insects and nematodes were found. Of them, $77.47 \%$ species were termites, $14.33 \%$ nematodes, $4.86 \%$ field crickets, $2.63 \%$ mole crickets and $0.72 \%$ cockchafer grubs. The individual of live wood termite (Microtermes obesi) was the highest whereas dagger nematode (Xiphinema sp) was the lowest in number (Table 3). In the study area, 15 species of beneficial insects were recorded. $81.49 \%$ species were being predator, $16.73 \%$ parasitoid and $1.78 \%$ parasite. The highest number of beneficial insects belonged to the lady bird beetle (Hippodamia convergens) and the lowest number to the anthocorids (Anthocoris sp.). Among the beneficial insects, the beetles (Coleoptera: Coccinellidae) were dominant (Table 4). A total of 19 species of butterflies belonging to five families under Lepidoptera order was observed. The butterflies of Pieridae family were predominant. Among them, the highest number of butterfly species was lemon emigrant (Catopsilia pomona) and the lowest was large oakblue (Arhopala amantes) (Table 5).

\section{Seasonal abundance of insect species}

Seasonal abundance of tea pests varied to a greater extent. The populations of major pests were present throughout the year. Helopeltis sp. invasion was found between April and August and again from October to the end of November, while the occurrence of red spider mite was observed between March and June and again from September and November. Thrips was prevalent during the end of February to July and again from the middle of September to the end of November. On the other hand, looper caterpillar was found during February-March and June-September. In case of termite, population started to increase from the months of November to April. It was found that nematode population was higher during April-September. Occurrence of major pests was also found overlapping in the next generation under prevailing climatic conditions 


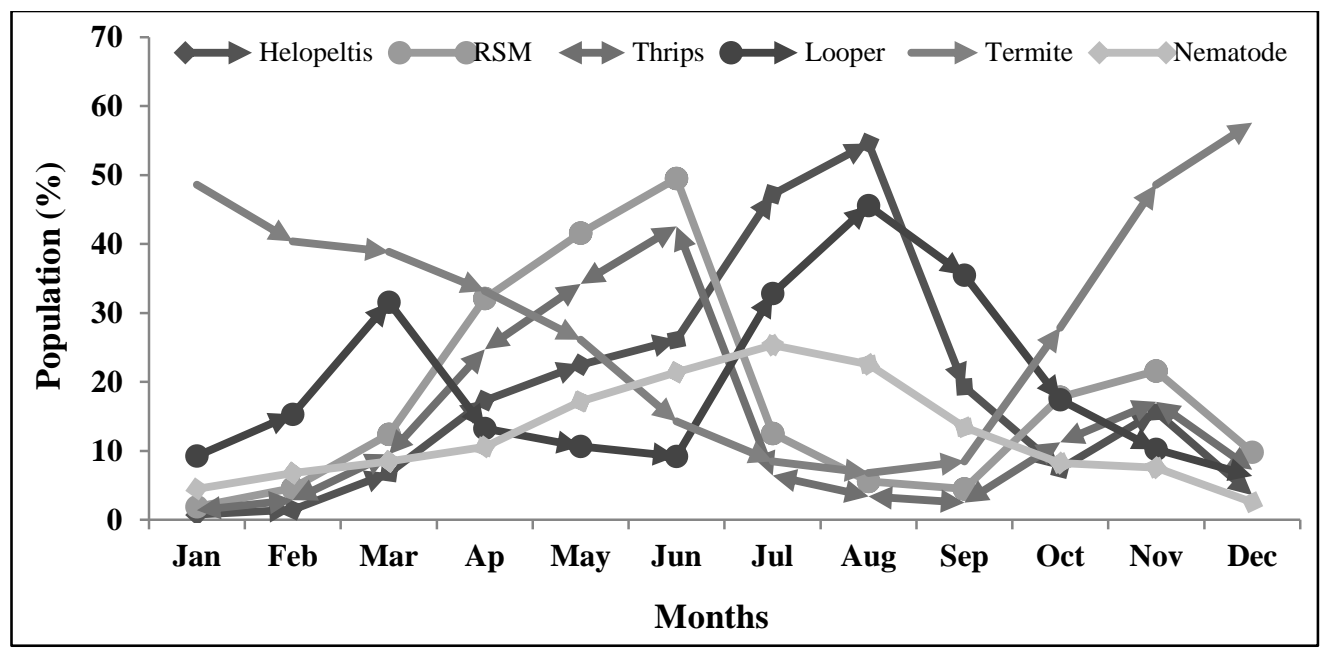

Fig. 2. Seasonal abundance of major insect, mite and nematode species in tea ecosystem.

Status and relative abundance of insect species

All the foliar and soil insects, mites and nematodes were found as recognized pests of tea among the identified species. Overall relative abundance showed that $86.82 \%$ species were foliar pests, $8.21 \%$ soil pests, $1.84 \%$ beneficial insects and $3.13 \%$ species were butterflies (Fig. 3 ).

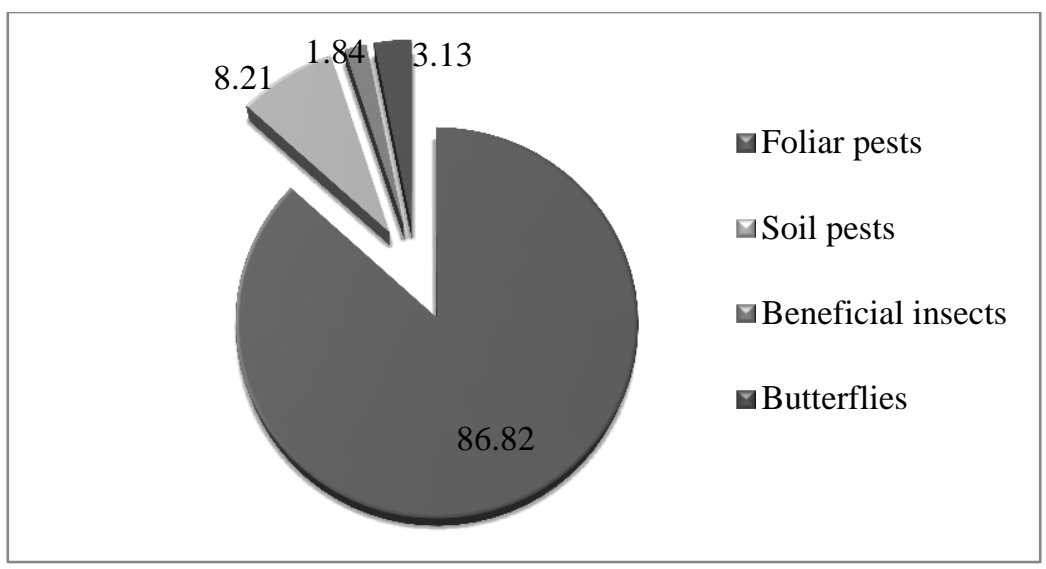

Fig. 3. Relative abundance of insect, mite and nematode species in the study area.

The relative abundance of individual pest population, i.e. low, medium and high depends on their degree of infestation and feeding capacity (Table 1). According to pest status, tea mosquito bug, red spider mite, thrips, looper caterpillar, live wood termites, root knot nematode and root lesion nematode were major pests and rest of those were occasional regarded as minor pests. Pest populations were found high in peak cropping season and the beneficial insects also increased during that time. Whereas, butterflies abundant in the months of March-July and October-December.

\section{Species diversity indices}

The calculated values indicate that the diversity of foliar insects (Simpson's Index of diversity = 0.846 and Shannon-Wiener's Index $=2.335$ ) was higher than the other groups observed (viz. soil insects, butterflies and beneficial insects). However, the foliar and soil insects were more evenly distributed (foliar insects $=0.808$ and soil insects $=0.759$ ) in comparison to butterflies and beneficial insects (Table 6). 
Table 1. Relative abundance of individual pest species.

\begin{tabular}{llccc}
\hline Name of the Pest & EIL & \multicolumn{2}{c}{ Relative abundance of individual pest species/plant } \\
\cline { 3 - 5 } & & Low & Medium & High \\
\hline Tea Mosquito Bug & 5\% shoot infestation & $<5$ & $5-10$ & $>10$ \\
Aphids & 20\% shoot infestation & $<6$ & $25-90$ & $>90$ \\
Thrips & 3 thrips per shoot & $<30$ & $60-200$ & $>200$ \\
Jassids & 50 nymphs per 100 leaves & $<5$ & $30-100$ & $>100$ \\
Looper caterpillar & 4-5 looper per plant & $<5$ & $5-10$ & $>10$ \\
Flush worm & 5 infested rolls per plant & $<5$ & $5-10$ & $>10$ \\
Leaf rollers & 5 infested rolls per plant & $<200$ & $200-1000$ & $>10$ \\
Red spider mite & 5 mites per leaf & $<30$ & $30-50$ & $>50$ \\
Termites & 10\% bush infestation & $<7$ & $7-15$ & $>15$ \\
Nematodes & 7 nnematodes per 10g soil & & & \\
\hline
\end{tabular}

EIL= Economic Injury Level

Tea, a perennial and monoculture crop grown in apparently isolated ecological zone in Bangladesh has formed virtual and stable ecosystem for widely divergent organisms. In this study, 23 insects, three mites, eleven nematodes were identified as tea pests. Previously, 25 insects, four mites and 10 nematodes were identified by Ahmed (2005) and Sana (1989) in Bangladesh tea. In the present investigation, one species of foliar insect, looper caterpillar (Hyposidra infixaria) and three species of nematodes, viz. reniform nematode (Rotylenchulus sp.), ring nematode (Criconemoides sp.) and dagger nematode (Xiphinema sp.) were recorded first time as tea pest in Bangladesh. Climate change and habitat loss due to deforestation might have promoted migration of new pest species in tea. Indiscriminate use of synthetic pesticides has also negative impact on natural enemies resulting pest resurgence and resurrection of minor pest to major one (Ahmed, 2005). Thrips and Looper caterpillar were also found as major pests.

According to feeding habit, the identified species were found as sucking, defoliating, feeding, leaf rolling, cutting, boring and bark feeding with the highest percentage of foliar insect's species. These species are similar to the other tea growing regions of the world (Chen and Chen 1989, Das 1965, Hamasaki et al. 2008, Muraleedharan 2005).

Most of the pest species identified in the present study are under Lepidoptera and Hemiptera orders. Ahmed (2005) and Chen and Chen (1989) found that among the Arthropod pests, Lepidoptera is the largest order in tea garden containing $32 \%$ of the pest species followed by Hemiptera with $27 \%$. The adaptations of insects, mites and nematodes have enabled them to attack every part of the tea plant and the maximum number of pests occur on foliage.

It was observed that seasonal abundance of tea pest varied to a greater extent. Availability of food, variety, age of plants and climate play an important role on population build up (Muraleedharan 2005). In peak cropping season, number of foliar pests and population were found high as well as the beneficial insects were also increased in that time. During this season climatic condition is suitable and food is relatively more available. Similarly, butterflies were found more in the flowering time of tea plant, shade trees and other forest plants in tea ecosystem. Insect populations were found low during off season. Because pruning operation was done in that time and food supply was limited. Among the 37 pest species, only tea mosquito bug, red spider mite, thrips, looper caterpillar, live wood termites, root knot nematode and root lesion nematode were found in all the study locations and caused a substantial crop loss in most of the time during the study period. In some cases, the individual population size was found more in minor pests. Whereas potential yield loss not only depends on population size but also on degree of infestation, feeding capacity, distributional pattern and seasonal abundance of individual pest species (Ahmed 1996). 
J. biodivers. conserv. bioresour. manag. 3(1), 2017

Table 2. List of foliar pest species observed in three study locations at Sreemangal from January 2014 to December 2015.

\begin{tabular}{|c|c|c|c|c|c|c|c|c|}
\hline Category & Order & Family & Scientific Name & Common Name & $\begin{array}{c}\text { Individuals } \\
\text { observed }\end{array}$ & Habitat & $\begin{array}{l}\text { Feeding } \\
\text { habit }\end{array}$ & Status \\
\hline \multirow{15}{*}{$\begin{array}{l}\stackrel{\mathscr{U}}{0} \\
\dot{\mathscr{D}} \\
\cong\end{array}$} & \multirow{6}{*}{ Hemiptera } & Miridae & Helopeltis theivora & Tea mosquito bug & 416 & Young leaves, shoots & Sucking & Major \\
\hline & & Jassidae & Empoasca flavescens & Jassid & 680 & Young leaves, shoots & Sucking & Minor \\
\hline & & Aphididae & Toxoptera aurantii & Aphid & 712 & Young leaves, shoots & Sucking & Minor \\
\hline & & Pentatomidae & Poecilocoris latus & Tea seed bug & 105 & Flowers, seed, bud & Sucking & Minor \\
\hline & & \multirow{2}{*}{ Coccidae } & Coccus viridis & Green scale & 680 & Leaves, shoots, stem & Sucking & Minor \\
\hline & & & Chrysomphalus aonidum & Florida red scale & 517 & Leaves, shoots, stem & Sucking & Minor \\
\hline & \multirow[t]{4}{*}{ Thysanoptera } & Thripidae & Scirtothrips dorsalis & Thrips & 1541 & Unopened \& partly opened bud & Sucking & Major \\
\hline & & Geometridae & Hyposidra infixaria & Looper caterpillar & 368 & Young \& mature leaves & Defoliating & Major \\
\hline & & Eucosmidae & Lespeyresia leucotoma & Flush worm & 190 & Two leaves \& a bud & Feeding & Minor \\
\hline & & Gracilaridae & Gracilaria theivora & Leaf roller & 104 & Young leaves & Leaf rolling & Minor \\
\hline & \multirow[t]{4}{*}{ Lepidoptera } & \multirow{2}{*}{ Psychidae } & Clania cramerii & Bag worm & 78 & Leaves, shoots, buds & Cutting & Minor \\
\hline & & & Clania sikkima & Faggot worm & 39 & Leaves, shoots, buds & Cutting & Minor \\
\hline & & Cossidae & Zeuzera coffeae & Coffee red borer & 19 & Stem & Boring & Minor \\
\hline & & Inderbelidae & Inderbela theivora & Bark eating borer & 39 & Stem & Bark feeding & Minor \\
\hline & Hymenoptera & Formicidae & Oecophylla amaragdina & Nest building ants & 855 & Older leaves & Tier & Minor \\
\hline \multirow{3}{*}{ 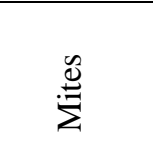 } & \multirow{3}{*}{ Acarina } & Tetranychidae & Oligonychus coffeae & Red spider mite & 5312 & Upper surface of the mature leaves & Sucking & Major \\
\hline & & Tenuipalpidae & Brevipalpus phoenicis & Scarlet mite & 948 & Under surface of the mature leaves & Sucking & Minor \\
\hline & & Triophyidae & Acaphylla theae & Pink mite & 685 & Surface of young \& mature leaves & Sucking & Minor \\
\hline
\end{tabular}


Table 3. List of soil pest species observed in three study locations at Sreemangal from January 2014 to December 2015.

\begin{tabular}{|c|c|c|c|c|c|c|c|c|}
\hline Category & Order & Family & Scientific Name & Common Name & $\begin{array}{c}\text { Individuals } \\
\text { observed }\end{array}$ & Habitat & $\begin{array}{l}\text { Feeding } \\
\text { habit }\end{array}$ & Status \\
\hline \multirow{8}{*}{$\begin{array}{l}\tilde{U} \\
\mathscr{U} \\
\Xi \\
\Xi\end{array}$} & Orthoptera & Gryllidae & Brachypterypes portensus & Field cricket & 61 & Stems, root, young plants & Cutting & Minor \\
\hline & & Gryllotalpidae & Gryllotalpa Africana & Mole cricket & 33 & Stems, root of young plants & Cutting & Minor \\
\hline & Isoptera & Termitidae & Microtermes obesi & Live wood termite & 293 & Root, stem, stump & Feeding & Major \\
\hline & & & Microcerotermes championi & Live wood termite & 165 & Root, stem, stump & Feeding & Major \\
\hline & & & Odontotermes feae & Scavenger termite & 71 & Root, stem, stump & Feeding & Minor \\
\hline & & & Odontotermes homi & Scavenger termite & 119 & Root, stem, stump & Feeding & Minor \\
\hline & & Rhinotermitidae & Coptotermes heimi & Live wood termite & 325 & Root, stem, stump & Feeding & Major \\
\hline & Coleoptera & Scarabaeidae & Melolontha melolontha & Cockchafer grub & 9 & Root & Feeding & Minor \\
\hline \multirow{11}{*}{$\begin{array}{l}\frac{n}{0} \\
\frac{0}{0} \\
\frac{\Xi}{0} \\
\mathbb{0} \\
Z\end{array}$} & Tylenchida & Pratylenchidae & Pratylenchus loosi & Root lesion nematode & 53 & Root & Sucking & Major \\
\hline & & Hoplolaimidae & Helicotylenchus sp. & Spiral nematode & 11 & Root & Sucking & Minor \\
\hline & & & Hoplolaimus sp. & Lance nematode & 7 & Root & Sucking & Minor \\
\hline & & & Rotylenchulus sp. & Reniform nematode & 9 & Root & Sucking & Minor \\
\hline & & Heteroderidae & Meloidogyne sp. & Root-knot nematode & 67 & Root & Sucking & Major \\
\hline & & Tylenchidae & Tylenchus sp. & Citrus nematode & 6 & Root & Sucking & Minor \\
\hline & & Aphelenchoididae & Aphelenchoides sp. & Dwarf nematode & 5 & Root & Sucking & Minor \\
\hline & & Criconematidae & Criconemoides sp. & Ring nematode & 7 & Root & Sucking & Minor \\
\hline & & Tylenchulidae & Paratylenchus sp. & Pin nematode & 6 & Root & Sucking & Minor \\
\hline & & Belonolaimidae & Tylenchorhynchus sp. & Stunt nematode & 5 & Root & Sucking & Minor \\
\hline & Dorylaimida & Longidoridae & Xiphinema sp. & Dagger nematode & 4 & Root & Sucking & Minor \\
\hline
\end{tabular}


J. biodivers. conserv. bioresour. manag. 3(1), 2017

Table 4. List of beneficial insect species observed in three study location at Sreemangal from January 2014 to December 2015.

\begin{tabular}{|c|c|c|c|c|c|c|c|}
\hline Order & Family & Scientific Name & Common Name & $\begin{array}{l}\text { Nature of action } \\
\text { on target pest }\end{array}$ & $\begin{array}{c}\text { Individuals } \\
\text { observed }\end{array}$ & $\begin{array}{c}\text { Host } \\
\text { Plants }\end{array}$ & Target pests \\
\hline Dictyoptera & Mantidae & Mantis sp. & Preying mantid & Predator & 23 & Tea & Helopeltis \\
\hline \multirow[t]{2}{*}{ Hemiptera } & Reduviidae & Euagoras plagiatus & Reduviid bug & Predator & 7 & Tea & Helopeltis \\
\hline & Anthocoridae & Anthocoris sp. & Anthocorids & Predator & 5 & Tea & Thrips \\
\hline \multirow[t]{2}{*}{ Neuroptera } & Chrysopidae & Chrysoperla carnea & Chrysoperla & Predator & 23 & Tea & Helopeltis, Aphid, Mites, Thrips \\
\hline & & Mallada boninensis & Green lacewing & Predator & 19 & Tea & Red spider mite, Helopeltis \\
\hline \multirow[t]{4}{*}{ Coleoptera } & Coccinellidae & Micraspis discolor & Lady bird beetle & Predator & 49 & Tea & Aphid, Mites \\
\hline & & Verania vincta & Verania beetle & Predator & 17 & Tea & Red spider mite \\
\hline & & Stethorus gilviforns & Stethorus beetle & Predator & 12 & Tea & Red spider mite \\
\hline & Staphylinidae & Oligota pygmaea & Staphylinid beetle & Predator & 19 & Tea & Red spider mite \\
\hline \multirow[t]{3}{*}{ Hymenoptera } & Braconidae & Bracon hebetor & Braconid wasp & Parasitoid & 39 & Tea & Flush worm \\
\hline & & Apanteles aristaeus & Apanteles & Parasitoid & 8 & Tea & Flush worm, Looper Caterpillar \\
\hline & Eulophidae & Sympiesis dolichogaster & Eulophid wasp & Parasite & 5 & Tea & Leaf roller \\
\hline Araneae & Oxyopidae & Oxyopes sp. & Spider & Predator & 35 & Tea & Helopeltis, Mites \\
\hline \multirow[t]{2}{*}{ Mesostigmata } & Phytoseiidae & Amblysieus herbicolus & Phytoseiid & Predator & 9 & Tea & Mites \\
\hline & & Amblyseius longispinosus & Predatory mite & Predator & 12 & Tea & Red spider mite \\
\hline
\end{tabular}


Table 5. List of butterfly species observed in three study location at Sreemangal from January 2014 to December 2015.

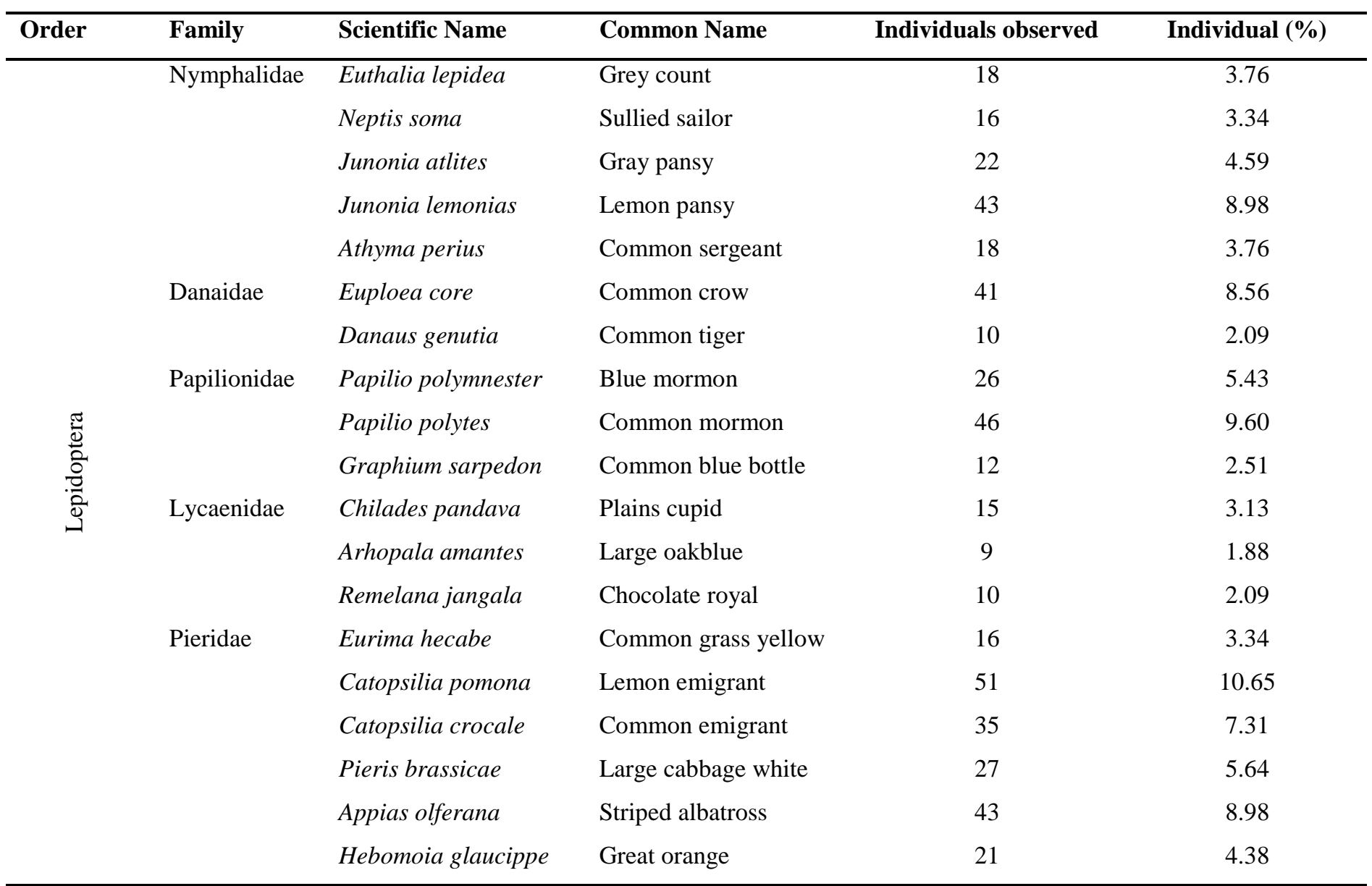

Table 6. Species diversity indices according to insect groups.

\begin{tabular}{lcccc}
\hline Parameter & Foliar insects & Soil insects & Beneficial insects & Butterflies \\
\hline Simpson's Index of diversity (D) & 0.846 & 0.813 & 0.769 & 0.795 \\
Shannon-Wiener Index (H) & 2.335 & 2.236 & 1.776 & 2.072 \\
Evenness (E) & 0.808 & 0.759 & 0.656 & 0.704 \\
\hline
\end{tabular}


Fifteen beneficial insects and nineteen butterfly species were found during the study period. In North-East India more than 100 species of beneficial insects were recorded (Borthakur et al. 2010). Bashar (2014) reported that 300 species of butterflies were found in Lawacherra national forest in 2002. The forest is nearby to the study area. Though the survey was done only in three tea estates, it is a matter of concern that their population is decreasing. Frequent use of pesticides and lack of adequate conservation technique might be the main reasons of population reduction of beneficial insects and butterflies in tea ecosystem. Human activities are more in tea ecosystem than forest areas which is also an important reason for low population of butterflies in tea ecosystem.

Tea cultivation in Bangladesh experiences diverse and complex insect species situation because it is being cultivated as mono crop adjacent to forest ecosystem. Different types of insects, mites and nematodes species are found in this study. Their interaction with ecology, seasonal abundance, distributional pattern, food habit is also understood which is very important to maintain stable biodiversity. Pesticides are integral part of pest management in tea. But, their indiscriminate use has detrimental effects on beneficial insects thereby disturbing the biodiversity and the balance in natural ecosystem. Non chemical methods of integrated pest management should be augmented. In case of chemical control, less toxic, selective pesticides should be preferred as much as possible, to maintain a stable biodiversity in tea ecosystem.

\section{REFERENCES}

Ahmed, M. 1996. Relationship between infestation intensity and crop loss by Helopeltis in Tea. Tea. J. Bangladesh. 32(1 and 2): 20-30.

Ahmed, M. 1997. Tea termites of Sylhet and their distinctive morphological characteristics. Tea J. Bangladesh. 33(1 and 2): 19-27.

Ahmed, M. 2005. Tea Pest Management. Evergreen Printing and Packaging. Dhaka. 101 pp.

Ahmed, M. 2014. Use of food traps for monitoring termite population in tea. Tea. J. Bangladesh. 43: 1014.

Alam, A. F. M. B. 1999. Profile of tea industry in Bangladesh. In: N. K. Jain (ed.). Global Advances in Tea Science. Aravali Books, New Delhi, India., pp. 1-22.

Anonymous. 2015. Statistics on Bangladesh tea industry. Project Development Unit (PDU), Bangladesh Tea Board, Sreemangal-3210, Moulvibazar, Bangladesh., pp. 26-30.

Anonymous. 2016. Annual Bulletin of Statistics. International Tea Committee (ITC). London, UK., pp. 48-54.

Antony, B., P. A. Sinu and A. Rahman. 2012. Looper caterpillar invasion in North-East Indian tea agroecosystem: Change of weather and habitat loss may be possible causes? J. Tea Sci. Res. 2(1): 1-5.

Bashar, M. A. 2013. Acharon-bichorone amader projapoti (Bangla version). A pictorial view of different butterflies in Bangladesh., pp. 2-31.

Bashar, M. A. 2014. Butterflies of Bangladesh: A broad approach for nature lovers. Vol. 1. 1st ed. BCTF publications, Dhaka-1000. 514 pp.

Bingham, L. C. T. 1907. The fauna of British India. Taylor and Francis, London. 2: 282-471.

Borthakur, M., A. Rahman and S. Sarmah. 2010. Pest management in tea in North East India. Bul. UPASI Tea Res. Found. 55: 10-18. 
Chen, Z and X. Chen. 1989. An analysis of the world tea fauna. J. Tea Sci. 9: 13-22.

Das, G. M. 1965. Pests of tea in North East India and their control. Memorandum No. 27. Tocklai Tea Research Institute, Tea Research Association, Jorhat, Assam, India., pp. 169-73.

Evans, G. O. 1992. Principles of Acarology. CAB International, Willingford: Cambridge, UK. 563 pp.

Hamasaki, R. T., R. Shimabuku and S. T. Nakamoto. 2008. Guide to insect and mite pests of tea (Camellia sinensis) in Hawaii. Cooperative Extension Services/CTAHR, University of Hawai, manoa, Honolulu, Hawaii., pp. 1-15.

Imms, A. D. (Revised by Richards, O.W. and Davies, R.G.). 1957. A General Textbook of Entomology. Methuen, London., pp. 1-1354.

Mai, W. F. and H. H. Lyon. 1975. Pictorial Key to Genera of Plant Parasitic Nematodes. Cornel University Press, Ithaca, NY. 219 pp.

Mamun, M. S. A., M. Ahmed and S. K. Paul. 2014. Integrated approaches in tea pest management for sustainable tea production. Proc. Workshop on Tea Production Technology Updated. Bangladesh Tea Research Institute, Sreemangal, Moulvibazar and Krishi Gobeshona Foundation, BARC Campus, Dhaka., pp. 18-32.

Mian, I. H. 1998. Introduction to Nematology. IPSA, Gazipur, Bangladesh., pp. 29-66.

Muraleedharan, N. 2005. Tea insects, ecology and control. In: D. Pimental (ed.). Encyclopledia of pest management. CRC press, India., pp. 672-674.

Ross, H. H. 1956. A Textbook of Entomology. John Wiley and Sons, Inc., New York., pp. 203-403.

Sana, D. L. 1989. Tea Science. Ashrafia Boi Ghar, 36, Bangla Bazar, Dhaka, Bangladesh., pp. 120-197.

Shannon, C. E. and W. Wiener. 1949. The mathematical theory. University of Illinois press, Urbana, USA. 117 pp.

Simpson, E. H. 1949. Measurement of diversity. Nature. 163: 688. 
J. biodivers. conserv. bioresour. manag. 3(1), 2017 